\title{
Occurrence of Bakanae Disease of Rice in Western Uttar Pradesh, India
}

\author{
Sachin Kumar Jain*, Kamal Khilari, Mukesh Dongre and Sanchita Pal \\ Department of Plant Pathology, S.V.P. Uni. of Agri. \& Technology, \\ Modipuram, Meerut-250110, India \\ *Corresponding author
}

\begin{tabular}{|l|}
\hline Ke y w o r d s \\
Rice; Bakanae \\
disease; Fusarium \\
moniliformae; \\
Gibberella fujikuroi
\end{tabular}

\section{Introduction}

Rice (Oryza sativa L.) is the second most popular cereal crop consumed and relished across the globe by around 2.7 billion people. Rice is using as staple food for about $50 \%$ of the world population (Rout, 2012) and $65 \%$ of Indian population. It contributes about half of the total food grain and $55 \%$ of total cereal production. India is the second largest producer of rice in the world followed to China and accounts for about 22 per cent of
Bakanae disease caused by Fusarium moniliformae Sheldon [Teleomorph- Gibberella fujikuroi] is a major rice disease in many rice growing countries including India. It is emerging as major problem of basmati rice in basmati producing areas of India and causing serious losses in basmati rice production. The symptoms of bakanae disease appear at all stages of crop from nursery to the maturity. To know the occurrence of bakanae disease, a survey was conducted during September, 2015 in the five districts (Meerut, Hapur, Gaziabad, Baghpat and Shamli) of Western Uttar Pradesh. During survey, it was observed that commonly grown rice varieties by the farmers of these districts are PB-1121, PB-1509, PB-1, Sarbati, and Sughandha-5. Among these varieties most preferred basmati rice variety is PB-1121 which was growing in 92 fields of 130 rice fields followed by PB-1509. Out of these five varieties, maximum bakanae disease prevalence $(100 \%)$ was observed in PB-1121 followed by $80 \%$ in PB-1509. The incidence of bakanae disease was observed in range of $3.4-7.8 \%$ in PB-1121 in all surveyed districts. Maximum disease incidence $(7.8 \%$ ) was observed in Baghpat district followed by Hapur (6.7\%). In all five districts, over all maximum average disease incidence $(5.32 \%)$ was observed in PB-1121. 
popular among farmers, is most susceptible for this disease (Khilari et al., (2011). This disease is caused by Fusarium moniliforme Sheldon, the pathogen was later identified as $F$. fujikuroi Nirenberg. The teleomorph stage of $F$. moniliforme is known as Gibberella fujikuroi Sawada [(Nirenberg (1976]. $F$. moniliforme induces seedling elongation, foot rot, seedling rot, grain sterility, and grain discoloration (Ou, 1985; Webster and Gunnell, 1992). The pathogen can be both seed-borne and soil borne. Generally, the seed-borne inoculum provides initial foci for primary infection. Infected plants in different foci have the capacity to produce numerous micro and macro conidia that subsequently infect other healthy plants, which lead to huge reduction in yield. Precise information on losses caused by this disease $15 \%$ was reported in Eastern districts of Uttar Pradesh of India and 40-50\% in Japan (Pavgi and Singh, 1964). Significant prevalence of bakanae disease has been reported from foothill regions of central Nepal and Philippines (Desjardins et al., 2000; Reyes, 1939). In India, bakanae disease has been reported in all basmati rice growing states like Eastern U.P., Assam, Andhra Pradesh, Tamilnadu, Haryana and Punjab (Rathaiah et al., 1991, Sunder et al., 1998 and Pannu et al., 2012). In the present investigation, a survey was carried out to known the prevalence and incidence of this disease in Western Uttar Pradesh.

\section{Materials and Methods}

To known the prevalence and incidence of bakanae disease, a survey was conducted during September 2015 in five districts (Meerut, Hapur, Gaziabad, Baghpat and Shamli) of Western U.P. In these five districts total 130 rice fields were surveyed randomly. In each field, an overall view of the rice crop obtained and made general observations for the presence or absence of disease symptoms to know the prevalence and to record the incidence of the bakanae disease.

\section{Prevalence percent}

The disease prevalence was recorded according to infected rice fields which showing the symptoms of bakanae disease.

Prevalence percent $=$

Rice field showing bakanae disease symptoms $\mathrm{X} 100$

Total rice field surveyed

\section{Disease incidence}

The disease incidence was recorded from the five sub plots (each sub plot has 100 rice plants) which were selected randomly in every sampling field. The percent disease incidence was calculated as follows (Teng and James, 2001).

Percent disease incidence $=$

Total number of infected plants

Total plants examined

\section{Results and Discussion}

During the survey of rice fields in Western Uttar Pradesh, it was observed that most prevalent symptom of bakanae disease is elongation of infected plants (Plate-1). Infected plants with bakanae disease becomes yellowish than healthy plants. The whitish growth of pathogen was appeared on node of the most infected plants (Plate-2). Some plants which were infected with bakanae disease have the panicle but the panicle of infected plants had chaffy and whitish in colour (Plate-3). Data of Table 1 clearly indicates that commonly growing varieties of rice are PB-1121, PB-1509, PB-1, Sarbati, 
and Sughandha-5 in five districts of Western U.P. Among these varieties, most preferred basmati rice variety is $\mathrm{PB}-1121$ which was growing in 92 fields of 130 rice fields followed by PB-1509 which was growing in 15 fields. In Meerut district most preferred rice varieties was $\mathrm{PB}-1121$ which was growing in 44 fields out of 62 fields. PB1509, PB-1 and Sugandha-5 have grown in 4, 6 and 5 fields out of 62 fields which were investigated during survey. The single field was found with sharbati, VB-21 and VB-22 varieties. In Hapur district 11 rice fields were investigated. Out of 11 rice fields, PB-1121 variety was growing in 7 fields. PB-1509, PB1, Sugandha-5 and Sarbati varieties was growing in 1, 1 and 2 fields respectively. In Gaziabad and Baghpat districts, 7 and 11 rice fields were investigated respectively. In both districts (Gaziabad and Baghpat), all investigated fields were observed with PB1121 variety. In the Shamli district, PB-1121 variety was growing in 23 fields out of 39 fields. Other rice varieties which have grown in Shamli district were PB-1509, PB-1 and Sarbati.

In all surveyed districts, PB- 1121 variety were sowing in 92 fields out of 130 rice fields (Table 2). It was observed that all field of PB1121 were infected with bakanae disease. So, bakanae disease prevalence $(100 \%)$ was observed in PB-1121. In PB-1121, average $5.32 \%$ disease incidence was observed in all districts. Fifteen fields out of 130 fields were sowing with PB-1509 variety of rice in which 12 fields were showing bakanae disease symptoms. In PB-1509, 80\% disease prevalence and average $1.5 \%$ disease incidence were observed. VB-22 variety of rice was found in single field with the infection of bakanae disease $(3.0 \%)$. In rest surveyed rice fields which were shown with PB-1, Sharbati, Sugandha-5 and VB21varieties were not observed with any infection of bakanae disease.

Table.1 District wise rice varieties in Western Uttar Pradesh

\begin{tabular}{|l|l|l|l|l|l|l|l|l|l|}
\hline $\begin{array}{l}\text { S. } \\
\text { No. }\end{array}$ & $\begin{array}{l}\text { Name of } \\
\text { district }\end{array}$ & $\begin{array}{l}\text { Total field } \\
\text { Surveyed }\end{array}$ & \multicolumn{9}{|c|}{ Rice varieties } \\
\cline { 4 - 10 } & & & PB-1121 & PB-1509 & PB-1 & Sugandha-5 & Sharbati & VB-21 & VB-22 \\
\hline $\mathbf{1}$ & Meerut & 62 & 44 & 4 & 6 & 5 & 1 & 1 & 1 \\
\hline $\mathbf{2}$ & Hapur & 11 & 7 & 1 & - & 1 & 2 & - & - \\
\hline $\mathbf{3}$ & Gaziabad & 7 & 7 & - & - & - & - & - & - \\
\hline $\mathbf{4}$ & Baghpat & 11 & 11 & - & - & - & - & - & - \\
\hline $\mathbf{5}$ & Shamli & 39 & 23 & 10 & 4 & - & 2 & - & - \\
\hline
\end{tabular}

Table.2 Bakanae disease prevalence and incidence in different rice varieties

\begin{tabular}{|l|c|c|c|c|}
\hline S. No. & Varieties & $\begin{array}{c}\text { Total no. of } \\
\text { Field }\end{array}$ & Infected field & $\begin{array}{c}\text { Average disease incidence } \\
\text { of total 5 districts }\end{array}$ \\
\hline $\mathbf{1}$ & PB-1121 & 92 & 92 & 5.32 \\
\hline $\mathbf{2}$ & PB-1509 & 15 & 12 & 1.5 \\
\hline $\mathbf{3}$ & PB-1 & 10 & 0 & 0.0 \\
\hline $\mathbf{4}$ & Sharbati & 5 & 0 & 0.0 \\
\hline $\mathbf{5}$ & Sugandha-5 & 6 & 0 & 0.0 \\
\hline $\mathbf{6}$ & VB-21 & 1 & 0 & 0.0 \\
\hline $\mathbf{7}$ & VB-22 & 1 & 1 & 3.0 \\
\hline Total & & $\mathbf{1 3 0}$ & $\mathbf{1 0 5}$ & \\
\hline
\end{tabular}


Table.3 District wise bakanae disease incidence in Western Uttar Pradesh

\begin{tabular}{|l|l|l|l|l|l|l|l|l|}
\hline $\begin{array}{l}\text { S. } \\
\text { No. }\end{array}$ & $\begin{array}{l}\text { Name } \\
\text { district }\end{array}$ & of & \multicolumn{7}{|l|}{ Disease incidence (\%) in different rice varieties } \\
\cline { 3 - 9 } & & $\begin{array}{l}\text { PB- } \\
\mathbf{1 1 2 1}\end{array}$ & $\begin{array}{l}\text { PB- } \\
\mathbf{1 5 0 9}\end{array}$ & $\mathbf{P B - 1}$ & $\begin{array}{l}\text { Sugandha- } \\
\mathbf{5}\end{array}$ & Sharbati & VB- & VB-22 \\
$\mathbf{1}$ & Meerut & 4.6 & 1.5 & 0.0 & 0.0 & 0.0 & 0.0 & 3.0 \\
\hline $\mathbf{2}$ & Hapur & 6.7 & 0.4 & - & 0.0 & 0.0 & - & - \\
\hline $\mathbf{3}$ & Gaziabad & 4.1 & - & - & - & - & - & - \\
\hline $\mathbf{4}$ & Baghpat & 7.8 & - & - & - & - & - & - \\
\hline $\mathbf{5}$ & Shamli & 3.4 & 1.7 & 0.0 & - & 0.0 & - & - \\
\hline
\end{tabular}

Plate.1 Bakanae disease infected plants in rice field (elongated)

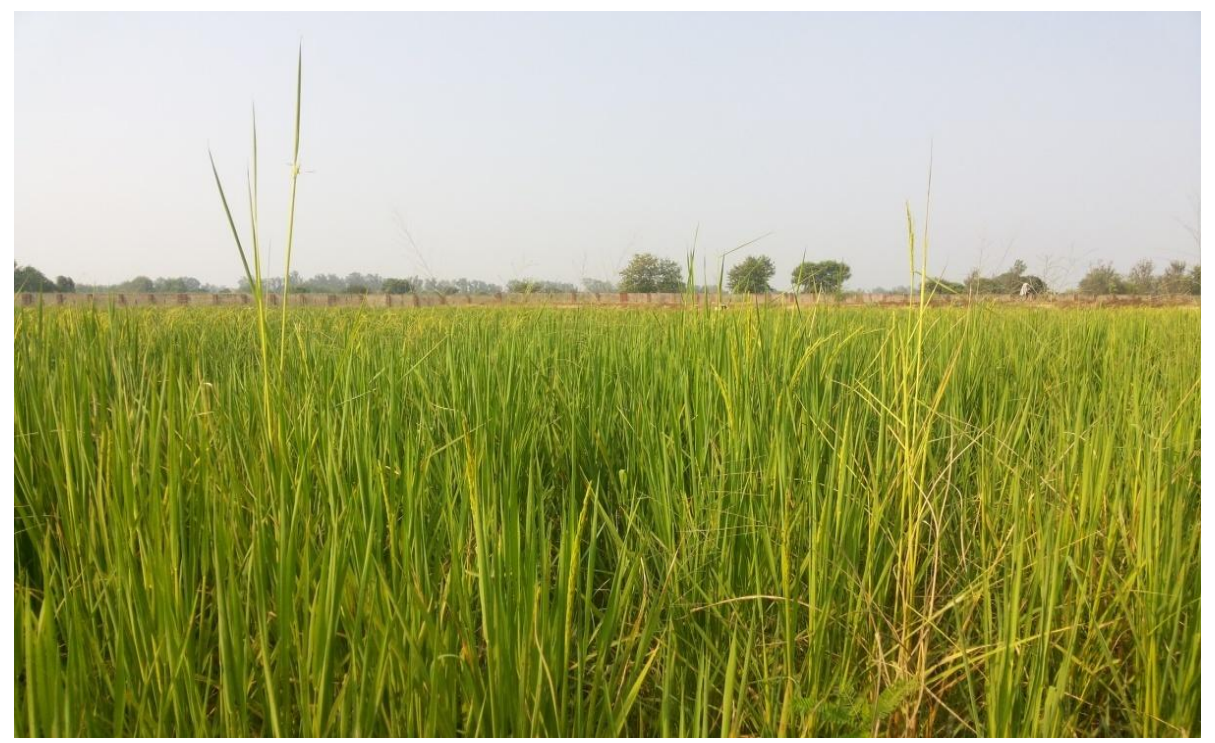

Plate.2 White growth of Fusarium moniliforme on nodes of infected rice plants

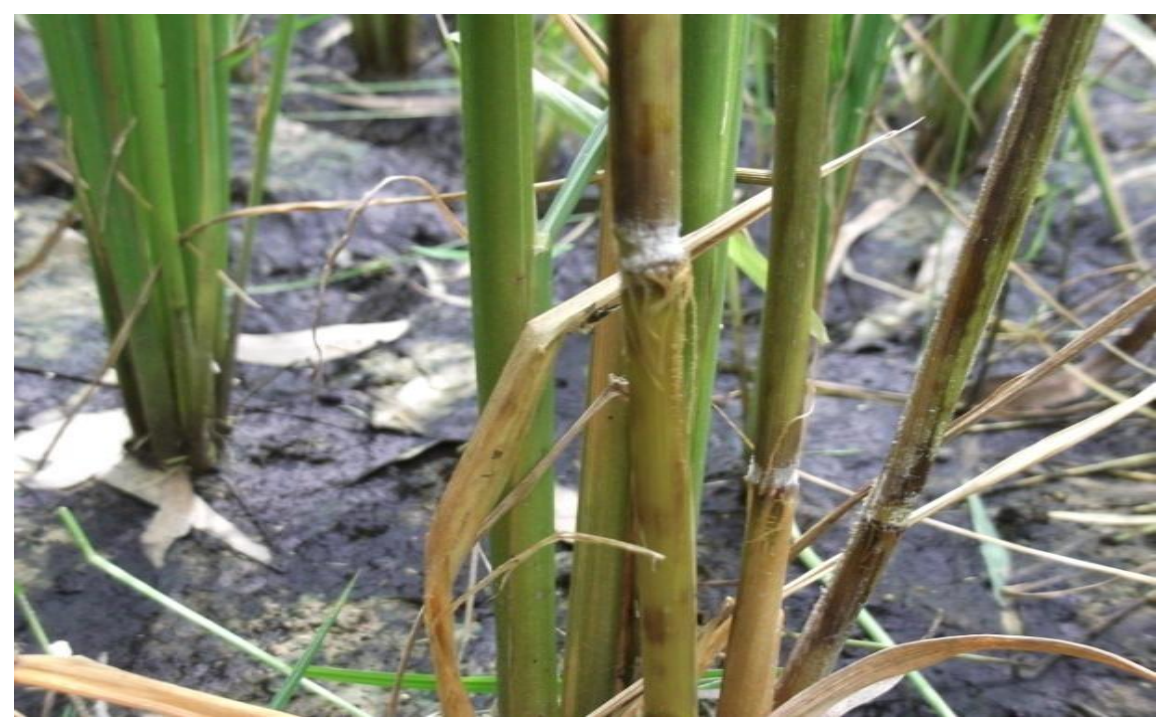


Plate.3 White ear head symptoms of bakanae disease

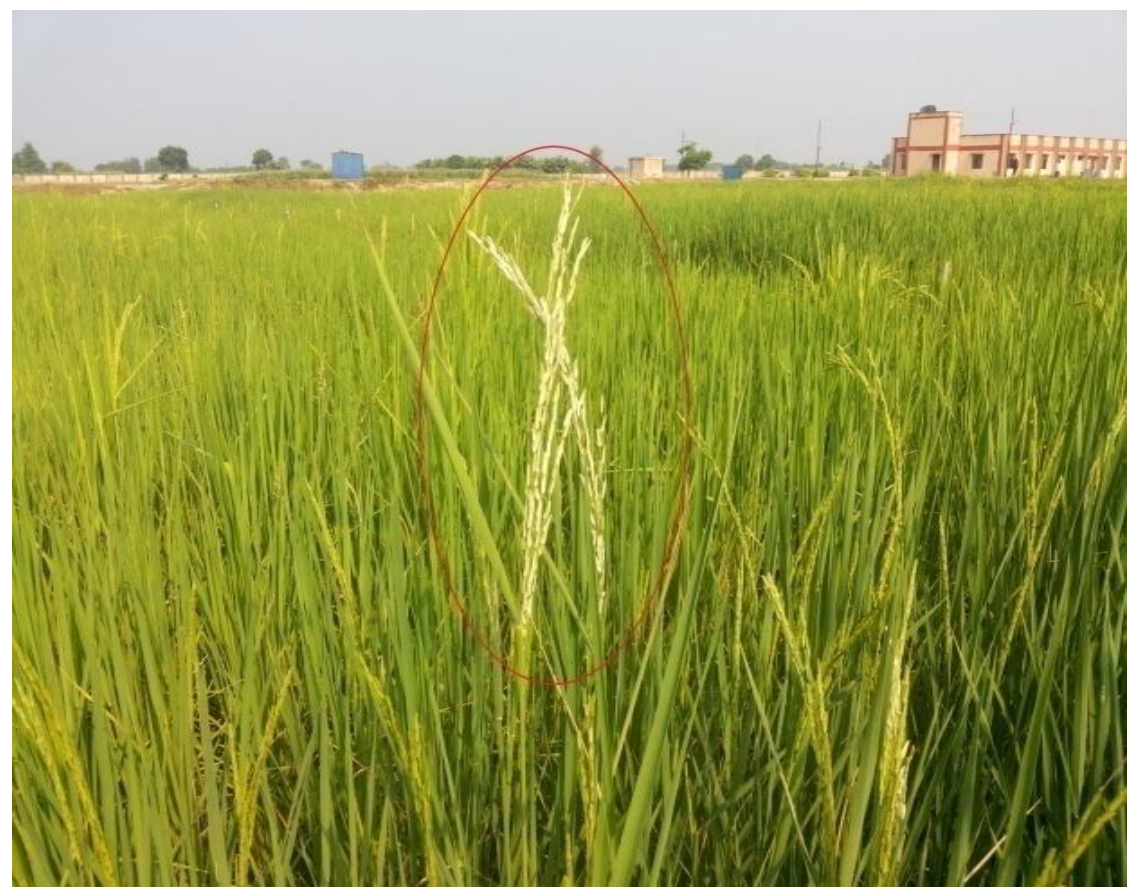

In Table 3 it is indicates that in Meerut district, three rice varieties (PB-1121, PB1509 and VB-22) were observed with bakanae disease infection. Disease incidence 4.6\% was observed in PB-1121 rice variety whereas PB-1509 and VB-22 were observed with 1.5 and $3.0 \%$ disease incidence respectively. In Hapur district, $6.7 \%$ disease incidence was observed in PB-1121 and 0.4\% disease incidence in PB-1509. In Gaziabad and Baghpat district, PB-1121 variety was observed with 4.1 and $7.8 \%$ disease incidence respectively. In Shamli district, 3.4 and $1.7 \%$ disease incidence was found in PB-1121 and PB-1509 variety respectively. In all surveyed districts, over all maximum incidence of bakanae disease was found in Baghpat $(7.8 \%)$ followed by Hapur (6.7\%) in PB-1121 variety of rice. No any infected plant with bakanae disease was found in PB-1, Sugandha-5 and Sarbati varieties in all surveyed districts.

Prevalence and incidence of bakanae disease have been reported in previous years by many researchers from many countries. Zainudin et al., (2008) reported that bakanae disease on rice distributed almost in all countries where paddy is grown commercially, especially in Asian countries, including Malaysia and Indonesia. Bakanae disease was widespread in Peninsular Malaysia and three provinces of Indonesia with the range of disease severity from scale 1 to 5 and disease incidence from 0.5 to $12.5 \%$. Basmati variety PB 1121 , which is most popular among farmers in all basmati area, is most susceptible for bakanae disease has been reported by Khilari et al., (2011). Hossain et al., (2013) reported that bakanae disease of rice is an important uprising disease in Bangladesh. At lowest (3\%) disease incidence the loss in yield was $1.32 \%$ and highest disease incidence it was as high as $22.64 \%$ in Aus season. Gupta et al., (2014) reported that bakanae disease is one of the newly emerged increasing problems of rice, particularly with basmati rice in northern India. The disease was found with $100 \%$ prevalence in all states/district surveyed viz., Uttar Pradesh, Uttarakhand, Punjab, Haryana, Rajasthan and Bihar. Disease incidence from 
1.2 - $11.7 \%$ in Uttar Pradesh, 2.1 - $3.2 \%$ in Uttarakhand, 10.5 - 40.00\% in Punjab, 2.1 $2.8 \%$ in Haryana, $2.4-13.6 \%$ in Rajasthan and $1.8-8.7 \%$ in Bihar was recorded on different basmati aromatic rice cultivars.

\section{Acknowledgements}

We would like to extend our sincere thanks to H.O.D. of Department of Plant Pathology, S. V. P. University of Agriculture and Technology, Meerut for providing the research facilities and encouraging to carry out this work.

\section{References}

Desjardins, A. E., Manandhar, H. K., Plattner, R. D., Manandhar, G. G., Poling, S. M., and Maragos, C. M. (2000). Fusarium species from Nepalese rice and production of mycotoxins and gibberellic acid by selected species. J. Appl. Environ. Microbiol.. 66: 1020-1025.

Gupta, A. K., Singh, Y., Jain, A. K. and Singh, D. (2014). Prevalence and Incidence of Bakanae disease of Rice in Northern India. Journal of Agri. Search, 1(4): 233-237.

Hossain, M. S., Ali, M. A., Mia, M. A. T., Islam, M. S. and Moni, Z. R. (2013). Estimation of yield loss by Fusarium moniliforme caused bakanae disease of rice. Eco-friendly Agril. J., 6(03): 40-43.

Khilari. K., Bhanu, C., Sharma, R., Gupta, A. and Gangwar, B. (2011). Bakanae disease- a serious threat to basmati rice cultivation. In proceeding Advances in Biotechnology in agriculture crops for sustaining productivity, quantity improvement and food security. $12 \mathrm{pp}$

Nirenberg, H. I. (1976). Untersuchungen uber die Morphologische and Biologische Differenzierung in Fusarium - Sektion Liseola. Mitt. Biol. Bundesansi. 169: 1-117.

Ou, S. H., (1985). Rice Diseases. Commonwealth Mycological Institute. Great Britain (UK). $380 \mathrm{pp}$

Pannu P. P. S., Kaur, J., Singh, G. and Kaur, J. (2012). Survival of Fusarium moniliforme causing foot rot of rice and its virulence on different genotypes of rice and basmati rice. Indian Phytopath., 65: 149-209.

Pavgi, M. S. and Singh, J. (1964). Bakanae and foot rot of rice in Uttar Pradesh, India. $P l$. Dis. Reptr., 48: 340-342.

Rathaiah, Y., Das, G.R. and Singh, K. H. U. (1991). Estimation of yield loss and chemical control of bakanae disease of rice. Oryza. 28: 509 - 512.

Sunder, S. S., and Singh, A. (1998). Screening of rice genotypes for resistance to bakanae disease. Indian Phytopath., 51: 299-300.

Teng P.S. and James W.C. (2001). Disease and yield loss assessment. In: 'Plant Pathologist's Pocketbook' (Waller JM, Lenne JM Waller, SJ eds.), pp. 25-38, CABI Publishing Company Inc. Boston, Massachussetts.

Webster, R. K. and P. S. Gunnell, (1992). Compendium of Rice Diseases. The American Phytopathological Society. APS Press, St. Paul, Minnesota, 62 pp

Zainudin, N.A.I.M., Razak, A.A. and Salleh, B. (2008). Bakanae disease of rice in Malaysia and Indonesia: Etiology of the causal agent based on morphological, physiological and pathogenicity characteristics. J. Plant Prot. Res., 48: 475-485.

\section{How to cite this article:}

Sachin Kumar Jain, Kamal Khilari, Mukesh Dongre and Sanchita Pal. 2019. Occurrence of Bakanae Disease of Rice in Western Uttar Pradesh, India. Int.J.Curr.Microbiol.App.Sci. 8(05): 207-212. doi: https://doi.org/10.20546/ijcmas.2019.805.025 